\title{
Early Markets: Fuel Cells for Material Handling Equipment
}

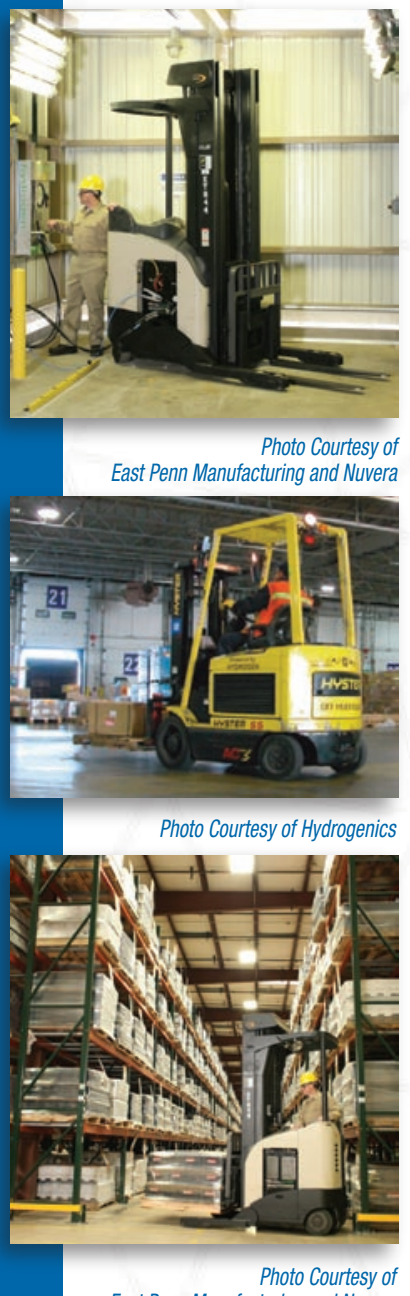

East Penn Manufacturing and Nuvera

\section{Overview}

Hydrogen can be used to power many end-use energy needs. Fuel cells which directly convert the chemical energy in hydrogen to electricity with only water and heat as byproducts are the key to making it happen.

Hydrogen polymer electrolyte membrane (also called proton exchange membrane or "PEM") fuel cells are leading candidates for use in fuel cell vehicles. Although it will be a while before fuel cell vehicles reach every dealer showroom, PEM fuel cells are commercially available today for some niche applications. One of these near-term markets is material handling equipment.

\section{The Case for Fuel Cells}

Lead-acid batteries are an established technology with proven reliability. From an operations and maintenance standpoint, however, there are several challenges. Batteries have a limited range, take substantial time to recharge and cool before reuse, are prone to voltage drops as power discharges, and create downtime during battery change-outs (which can take from 15 to 30 minutes in many operations).
For these reasons, on a lifecycle basis, PEM fuel cells can be cost competitive with batteries, particularly for continuously used forklift trucks running two or three shifts per day when multiple battery change-outs may be required.

Fuel cells are currently eligible for a Federal tax credit up to $\$ 1,000 / \mathrm{kW}$. In some situations, the operations and maintenance savings associated with fuel cells can provide a financially attractive payback. The higher cost of hydrogen, compared with conventional fuels or electricity (which also bears directly on the lifecycle economics), may be mitigated by generating it on-site.

Like batteries, PEM fuel cells produce no harmful emissions at the point of use. Unlike batteries, however, fuel cells can be rapidly refueled, eliminating the time and
Lifecycle Cost Comparison of PEM Fuel Celland Battery-Powered Forklifts

\begin{tabular}{|c|c|c|c|c|c|c|}
\hline & \multicolumn{3}{|c|}{$\begin{array}{l}\text { 3kW PEM FUEL CELL PAIRED WITH } \\
\text { INTEGRAL NiMH BATTERY, } \\
\text { FOR PALLET TRUCKS }{ }^{*}\end{array}$} & \multicolumn{3}{|c|}{$\begin{array}{l}\text { 8kW PEM FUEL CELL PAIRED WITH } \\
\text { INTEGRAL ULTRACAPACITOR, } \\
\text { FOR SIT DOWN RIDER TRUCKS }{ }^{\star \star}\end{array}$} \\
\hline & $\begin{array}{l}\text { BATTERY- } \\
\text { POWERED } \\
\text { ( } 2 \text { batteries } \\
\text { per truck) }\end{array}$ & $\begin{array}{l}\text { PEM FUEL } \\
\text { CELL- } \\
\text { POWERED, } \\
\text { WITHOUT } \\
\text { INCENTIVE }\end{array}$ & $\begin{array}{l}\text { PEM FUEL } \\
\text { CELL- } \\
\text { POWERED, } \\
\text { WITH } \\
\text { INCENTIVE }\end{array}$ & $\begin{array}{l}\text { BATTERY- } \\
\text { POWERED } \\
\text { ( } 2 \text { batteries } \\
\text { per truck) }\end{array}$ & $\begin{array}{c}\text { PEM FUEL } \\
\text { CELL- } \\
\text { POWERED, } \\
\text { WITHOUT } \\
\text { INCENTIVE }\end{array}$ & $\begin{array}{c}\text { PEM FUEL } \\
\text { CELL- } \\
\text { POWERED, } \\
\text { WITH } \\
\text { INCENTIVE }\end{array}$ \\
\hline $\begin{array}{l}\text { Net Present Value } \\
\text { of Capital Costs }\end{array}$ & $\$ 17,654$ & $\$ 23,835$ & $\$ 21,004$ & $\$ 43,271$ & $\$ 63,988$ & $\$ 56,440$ \\
\hline $\begin{array}{l}\text { Net Present Value } \\
\text { of O\&M Costs } \\
\text { (including the } \\
\text { cost of fuel) }\end{array}$ & $\$ 127,539$ & $\$ 52,241$ & $\$ 52,241$ & $\$ 76,135$ & $\$ 65,344$ & $\$ 65,344$ \\
\hline $\begin{array}{l}\text { Net Present } \\
\text { Value of Total } \\
\text { Costs of System }\end{array}$ & $\$ 145,193$ & $\$ 76,075$ & $\$ 73,245$ & $\$ 119,405$ & $\$ 129,332$ & $\$ 121,784$ \\
\hline
\end{tabular}

Source: Identification and Characterization of Near-term Direct Hydrogen Proton Exchange Membrane Fuel Cell Markets, Battelle Memorial Institute (April 2007).

*Assumptions: Operate 7 hours/shift, 3 shifts/day, 7 days/week; batteries changed out every shift, taking about 30 minutes; operator cost $\$ 15 /$ hour; PEM fuel cell fork lift uses 3kW stacks with NiMH batteries; PEM fuel cell stack replaced every 5 years at $\$ 3,000 / \mathrm{kW}$; batteries replaced every 5 years at $\$ 1,800$; PEM fuel cell forklift refueled once every shift, refueling time 1 minute; no disposal costs were assumed for any of the technologies.

**Assumptions: Operate 7 hours/shift, 3 shifts/day, 7 days/week; batteries changed out every shift, taking about 15 minutes; operator cost \$15/hour; PEM fuel cell fork lift uses $8 \mathrm{~kW}$ stacks with ultracapacitors; PEM fuel cell stack replaced every 5 year at $\$ 3,000 / \mathrm{kW}$; batteries replaced every 5 years at $\$ 4,000$; PEM fuel cell forklift refueled once every shift, refueling time 3 minutes; no disposal costs were assumed for any of the technologies.. 


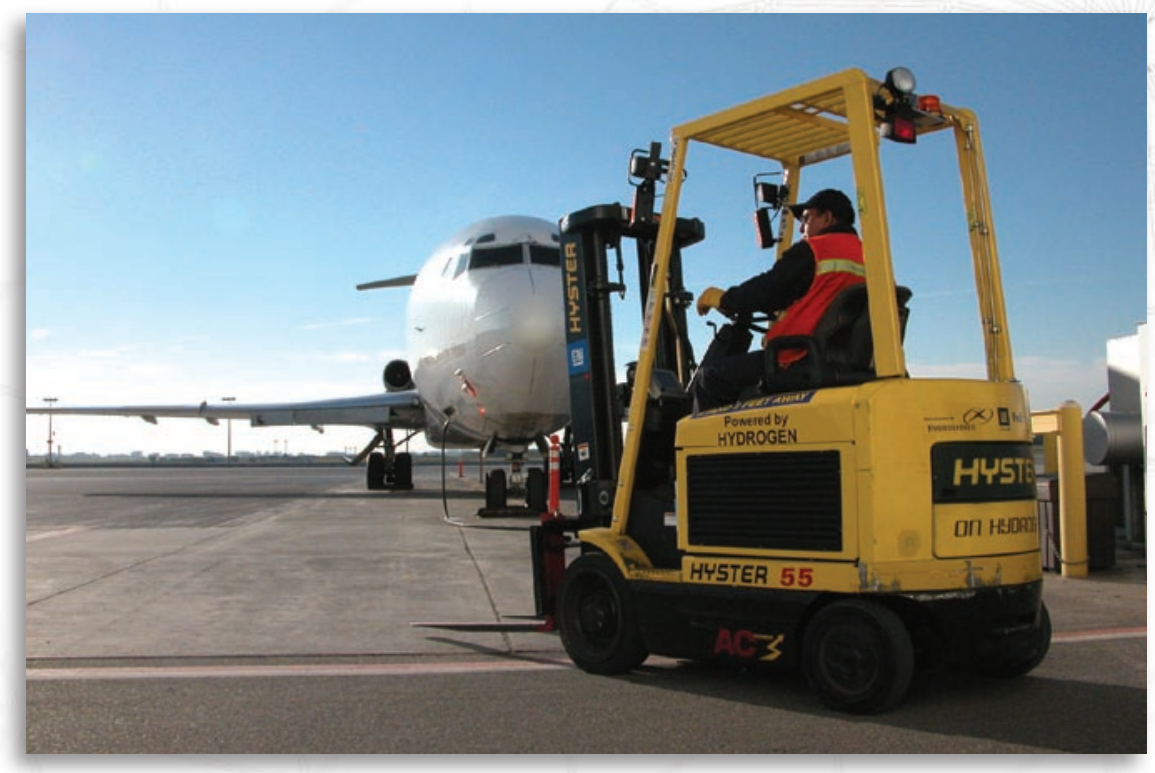

PEM fuel cell forklifts such as this one can increase productivity and can be cost competitive on a lifecycle bases for continuous use operations.

Photo Courtesy of Hydrogenics

cost associated with swapping batteries. The voltage delivered by the fuel cell is constant as long as hydrogen fuel is supplied. Using fuel cell-powered forklifts can boost productivity by eliminating trips to the battery changing station. And with no chargers, battery storage, or changing areas or equipment needed, more warehouse space is available.

\section{Practical Use}

Several fuel cell pilot projects are already under way, including a collaboration involving Hydrogenics, NACCO, General Motors, and Federal Express; a hydrogen and fuel cell trial at The Raymond Corporation in Greene, New York; and a purpose-built fuel cell truck by Toyota Material Handling. East Penn Manufacturing Co., Inc., a leading industrial battery supplier, has converted all ten of its electric reach trucks running at its distribution center in Topton, Pennsylvania, to fuel cell power using a hybrid battery/fuel cell power pack developed in partnership with Nuvera Fuel Cells. Also, Cellex Power Products has completed a four-month trial of twelve Crown forklifts at two WalMart distribution centers in Ohio. The trial showed improved productivity from refueling-time savings, saved floor space, and high user satisfaction. For more on this project, please visit www.eere.energy.gov/hydrogenandfuelcells/ education/pdfs/cellex_report_odod.pdf.

\section{Contacts}

DOE Hydrogen Program Peter Devlin

Phone: 202-586-4905

Email: peter.devlin@ee.doe.gov

Battelle Memorial Institute

Kathya Mahadevan

Statistics and Information

Analysis

Phone: 614-424-3197

Email: mahadevank@battelle.org

To read the full report, Identification and Characterization of Near-term Direct Hydrogen Proton Exchange Membrane Fuel Cell Markets, completed by Battelle Memorial Institute for the U.S. Department of Energy, please visit www.eere.energy. gov/hydrogenandfuelcells/fc_ publications.html.

Increase Your H2IQ!

Visit www.hydrogen.energy.gov

Produced by the National Renewable Energy Laboratory (NREL)

NREL is a U.S. Department of Energy National Laboratory operated by Midwest Research Institute $\bullet$ Battelle 